\title{
TELAAH PENERAPAN PSAK 45 DAN PSAK 109 \\ DALAM REKONSTRUKSI AKUNTANSI \\ PELAPORAN KEUANGAN MASJID \\ (Sebuah Studi Literatur)
}

\author{
Fuad Yanuar AR, Widad Sarah Hanifah \\ STAIA Syubbanul Wathon Magelang \\ fyarc86@gmail.com
}

https://doi.org/10.46367/jas.v4i1.208

Received: Apr 05, 2020 Revised: Mei 26, 2020 Accepted: Mei 28, 2020 Published: Jun 25, 2020

\begin{abstract}
This research discusses the use of PSAK 45 and PSAK 109 in mosque financial reporting. The discussion focused on the concept of comprehensive and ideal implementation of mosque financial reporting. The results of the literature review of PSAK 45 and PSAK 109 ideally mosque financial statements should use PSAK 45 because the assumptions and management of mosques are far more complex sources and their use is not only about zakat and its distribution. However, the side of the simplicity of reporting and not reducing PSAK 45 rules is important in the disclosure and financial reporting of mosques. The mosque is also a zakat distribution body for reporting using PSAK 109 in a separate section.
\end{abstract}

Keywords: PSAK 45, PSAK 109, Mosque Accounting, Accounting Reconstruction.

\begin{abstract}
ABSTRAK
Penelitian ini membahas pada penggunaan PSAK 45 dan PSAK 109 dalam pelaporan keuangan masjid. Pembahasan menitikberatkan pada konsep implementasi komprehensif dan ideal dari pelaporan keuangan masjid. Hasil dari telaah literatur terhadap PSAK 45 dan PSAK 109 secara ideal laporan keuangan masjid seharusnya menggunakan PSAK 45 karena asumsi dan yang dikelola masjid jauh lebih kompleks sumber dan penggunaanya tidak hanya tentang zakat dan penyalurannya. Akan tetapi sisi dari penyerderhaan dari pelaporan dan tidak mengurangi kaidah PSAK 45 itu yang menjadi penting dalam pengungkapan dan pelaporan keuangan masjid. Masjid juga merupakan badan penyalur zakat maka untuk pelaporannya menggunakan PSAK 109 dalam bagian yang terpisah.
\end{abstract}

Kata Kunci: PSAK 45, PSAK 109, Akuntansi Masjid, Rekonstruksi Akuntansi.

\section{PENDAHULUAN}

Dalam akuntansi dibedakan menjadi dua menurut jenisnya yaitu akuntansi private atau swasta dan akuntansi sektor publik. akuntansi sektor private adalah yang digunakan pada perusahaan atau organisasi yang mencari laba. akuntansi sektor publik yaitu yang digunakan pada organisasi sektor publik atau organisasi yang dimilik oleh masyarakat dan digunakan oleh masyarakat dan memiliki 
kompleksitas yang lebih tinggi serta memiliki wilayah yang lebih luas dibanding organisasi private atau swasta. Keluasan wilayah disebabkan luasnya jenis dan bentuk organisasi yang berada di dalamnya dan karena kompleknya lingkungan yang memengaruhi lembaga lembaga publik tersebut yang merujuk pada organisasi pemerintah atau Negara (Halim 2008, 251 dan Mardiasmo 2009). Bastian (2006) dan Untoro (2010) merujuk organisasi sektor publik organisasi yang menggunakan dana masyarakat, seperti: Organisasi Pemerintah Pusat, Organisasi Pemerintah Daerah, Organisasi Partai Politik dan Lembaga Swadaya Masyarakat, Organisasi Yayasan, Organisasi Pendidikan dan Kesehatan (puskesmas, rumah sakit, dan sekolah), Organisasi Tempat Peribadatan (masjid, gereja, vihara, kuil) (Azwari 2018).

Tempat ibadah juga merupakan organisasi sektor publik, karena yang memiliki masyarakat dan digunakan oleh masyarakat. Masjid yang merupakan tempat ibadah tidak terlepas dari kompleksitas yang tinggi karena tidak hanya sebagai tempat ritual sholat tetapi juga sebagai centre of activity yaitu sebagai tempat organisasi memiliki peranan yang sangat strategis dalam peningkatan kesejahteraan masyarakat, bahkan tidak kalah strategisnya dengan jenis organisasi publik lainnya. Pusat aktivitas ini meliputi berbagai bidang, seperti pendidikan, ekonomi, sosial,budaya dan hukum. Tempat ibadah sebagai sebuah organisasi dan memiliki tujuan yang akan dicapai melalui alat organisasional, seperti dalam hal pengelolaan keuangan masjid juga mempunyai komplesitas yang tinggi dan itu yang disebut akuntansi.

Organisasi sering diartikan sebagai entitas dan dalam akuntansi, entitas dan akuntansi tidak bisa terpisahkan. Karena dalam konsep dasar akuntansi ada asumsi entitas akuntansi. Konsep itu menjelaskan bahwa semua transaksi keuangan yang diakuntansikan adalah yang berkaitan dengan entitas (kesatuan atau organisasi) yang dilaporkan (Halim 2013). Argumen itu menjelaskan bahwa akuntansi akan lebih berguna kepada entitas keagamaan jika masjid sebagai tempat peribadatan bukan hanya sebagi ritual sholat tetapi juga sebagai organisasi atau entitas keagamaan yang melekat pada konsep entitas dan akuntansi.

Keterlibatan aspek keagamaan menimbulkan pertanyaan kesesuaian akuntansi dengan ajaran agamadan aturannya. Salah satu yang menyebabkan kurangnya kesadaran akan pentingnya akuntansi dalam pengelolaan keuangan tempat ibadah adalah adanya anggapan bahwa akuntansi merupakan produk ilmu pengetahuan manusia yang tidak ada dalam cakupan ajaran agama. Peran penting akuntansi terlihat jika tempat ibadah diposisikan sebagai entitas atas satuan organisasi.Jika tempat ibadah merupakan sebuah organisasi, maka organisasi tempat ibadah termasuk dalam kategori organisasi apa Organisasi peribadatan tidak bermotif untuk mencari laba dan bertujuan melayani ritual ibadah umat, maka organisasi peribadatan termasuk dalam kategori organisasi nirlaba. Kebanyakan organisasi nirlaba menggunakan beberapa parameter tunggal sebagai ukuran keberhasilannya, seperti jumlah danasumbangan yang diperoleh, pertumbuhan jumlah anggota jumlah pengunjung, jumlah orang yang dilayani, dan biaya overhead yang mampu diminimalisasikan (Bastian, 2007). Organisasi tempat ibadah juga disebut organisasi keagamaan (Bastian: 2007). Organisasi keagamaan mengacu padaorganisasi dalam sebuah tempat peribadatan seperti Masjid,Mushola, gereja, Kapel, Kuli, Klenteng, Wihara maupun Pura. Organisasi keagamaan dijalankan oleh sebuah lembaga atau organisasi yang muncul atas 
kesadaran akan berjalannya visi dan misi agama tertentu (Bastian, 2007: 216) (Azwari 2018).

Secara umum masjid terdiri dari Muadzin, Khotib, Imam dan Jamaah. Dan dalam masjid ada beberapa orang yang bertugas untuk yang kerjanya identik dengan pengelola semua urusan yang berkaitan dengan masjid yang disebut takmir masjid. Banyak kendala yang dihadapi masjid pada umumnya yaitu banyak yang menjadi takmir itu orang-orang yang sudah tua dan dalam kapasitas manajerialnya sangat kurang karena ini bekerja dengan level keikhlasan yang tinggi dan ini semua menjadi tantangan keberlangsungan masjid kedepan. Masalah yang sangat penting muncul tentang dana masyarakat atau hibah dan pelaporan keuangan sesuai standar akuntansi.

Masjid sebagai organisasi nirlaba harus dan berhak melaporkan kepada pengguna pihak yang berkepentingan. Ini adalah kehidupan alami dan pengembangan organisasi masjid berasal dari sumbangan, sedekah, atau bentuk bantuan sosial lainnya. Organisasi harus membuka diri kepada masyarakat umum untuk mendapatkan informasi yang benar, jujur, dan tidak diskriminatif, setidaknya dengan anggota organisasi keagamaan tersebut. Informasi dapat diakses oleh siapa saja yang menggunakan mekanisme tertentu, agar tidak disalahgunakan oleh mereka yang berniat buruk terhadap organisasi. Konsekuensi ini menjadi kewajiban yang harus dipenuhi karena pertanggungjawaban organisasi masjid akan sangat mempengaruhi tingkat kepercayaan masyarakat terhadap organisasi masjid itu sendiri (Rahayu et al. 2017 dalam Azwari 2018).

Menurut penelitian Rahayu et al (2017) Prinsip akuntabilitas praktik akuntansi di Surabaya Al Akbar National Mosque dilihat sebagai bagian dari ibadah. Pola pertanggungjawaban bersifat vertikal, kepada Badan Pengawas Nasional Surabaya Al Akbar National Mosque, Pemerintah Provinsi Jawa Timur, dan Allah SWT sebagai upaya untuk mendapatkan berkah-Nya, sedangkan akuntabilitas horisontalnya adalah untuk masjid dan komunitas donor. Lebih lanjut Rahayu et al (2017) mengatakan Implementasi transparansi pada laporan keuangan Al Akbar National Mosque dilakukan dengan memberikan informasi yang jelas tentang prosedur, biaya, dan tanggung jawab Dewan Manajemen Masjid, menyediakan akses mudah ke informasi laporan keuangan, menyiapkan mekanisme pengaduan dalam hal pelanggaran peraturan, dan peningkatan arus Informasi melalui kerjasama dengan media massa dan organisasi non-pemerintah Surabaya.

Pengelolaan keuangan masjid menjadi penting untuk dikaji karena masjid merupakan pusat kegiatan dari kaum muslim di seluruh dunia tak terkecuali Indonesia. Ikatan Akuntan Indonesia (IAI) merupakan lembaga yang berwenang mengeluarkan standar akuntasi. Pembentukan standar akuntansi untuk pengelolaan masjid yang merupakan entitas sektoe publik dan nirlaba yaitu PSAK 45 dan PSAK 109. PSAK 45 mengatur tentang pelaporan keuangan organisasi nirlaba dan masjid juga termasuk dari organisasi nirlaba karena dalam menjalankan aktivitasnya tidak mendapatkan laba. Kriteria organisasi nirlaba hampir sama dengan kriteria di masjid yaitu yang pertama sumber daya berasal dari para penyumbang dan tidak mengharapkan pembayaran kembali, yang kedua menghasilkan barang dan jasa tanpa bertujuan memupuk laba dan yang ketiga tidaka adanya kepemilikan seperti lazimnya organisasi bisnis lainnya. dan juga untuk PSAK 109 yang mengatur tentang akuntansi zakat,infak dan sodaqoh yang 
biasanya itu menjadi sumber dana yang didapat oleh masjid. Penelitian ini akan memfokuskan dalam membandikan PSAK 45 dan PSAK 109 sebagai dasar pelaporan keuangan masjid yang paling sesuai digunakan.

\section{TELAAH LITERATUR}

\section{Akuntansi Masjid}

Akuntansi masjid adalah kegiatan jasa dalam tata buku dan pengelolaan transaksi yang terjadi dalam kegiatan operasional masjid. Tata buku atau rangkaian kegiatan yang dilakukan secara sistematis dalam bidang keuangan, berdasarkan prinsip, standardisasi, dan prosedur tertentu untuk menghasilkan informasi aktual di bidang keuangan dalam organisasi masjid yang melibatkan para anggota, umat, atau pengikut agama di organisasi keagamaan yang bersangkutan (Halim dan Kusufi, 2016). Peran akuntansi akan terlihat jika tempat ibadah atau masjid diposisikan sebagai entitas atau satuan organisasi (Halim dan Kusufi, 2016). Mengenalkan akuntansi pada organisasi masjid berarti lebih berorientasi untuk menumbuhkan kesadaran kepada pengelola masjid tentang pentingnya praktik akuntansi dalam pengembangan organisasi masjid (Halim dan Kusufi, 2016). Akuntansi dijadikan pengurus masjid sebagai tools positif secara material tetapi distortif bagi teologi Islam (Simanjuntak dan Januarsi, 2011).

Islam sangat erat kaitannya dengan akuntansi, dengan turunnya Surat AlBaqarah Ayat 282 dijelaskan tentang pencatatan, pendokumentasian, saksi dan utang secara mendetail dalam surat itu. Dapat ditarik kesimpulan bahwa islam mengajarkan pencatatan dalam Islam itu signifikansi, pencatatan itu dapat menjadikan entitas keagamaan dapat bekerja dengan baik.Pencatatan keuangan dalam suatu entitas keagamaan (Masjid) dapat menjadi ukuran kinerja para pengurus Masjid atau Takmir Masjid khususnya yang diamanahkan sebagai bendahara keuangan.Penelitian yang dilakukan oleh Kerry Jacob (2004) dalam Simanjutak dan Januarsih (2011) yang menjelaskan bahwa akuntansi mampu mendorong kerja entitas keagamaan menjadi lebih baik ketika peran akuntansi di maksimalkan di lembaga keagamaan tersebut.

\section{PSAK 45}

Standar yang mengatur dan memebrikan tujuan pelaporan keuangan pada organisasi nirlaba untuk menyediakan informasi yang relevan kepada pihak yang berkepentingan terutama penyumbang dana, anggota organisasi, krediturdan pihak lain yang memebrikan sumbangsih kepada organisasi nirlaba. pelaporan keuangan entitas nirlaba yang mudah dipahami, memiliki relevansi, dan memiliki daya banding yang tinggi.

Definisi dalam pembatasan permanen adalah pembatasan penggunaan sumber daya yang ditetapkan oleh pemberi sumber daya yang tidak mengharapkan pembayaran kembali agar sumber daya tersebut dipertahankan secara permanen, tetapi entitas nirlaba diizinkan untuk menggunakan sebagian atau semua penghasilan atau manfaat ekonomik lain yang berasal dari sumber daya tersebut. Pembatasan temporer adalah pembatasan penggunaan sumber daya oleh pemberi sumber daya yang tidak mengharapkan pembayaran kembali yang menetapkan agar sumber dayatersebut dipertahankan sampai dengan periode tertentu atau sampai dengan terpenuhinya keadaan tertentu. Sumber daya 
terikat adalah sumber daya yang penggunaannya dibatasi untuk tujuan tertentu oleh pemberi sumber daya yang tidak mengharapkan pembayaran kembali. Pembatasan tersebut dapat bersifat permanen atau temporer. Sumber daya tidak terikat adalah sumber daya yang penggunaannya tidak dibatasi untuk tujuan tertentu oleh pemberi sumber daya yang tidak mengharapkan pembayaran kembali.

Jenis-jenis Laporan Keuangan Entitas Nirlaba Unsur-unsur laporan keuangan berdasarkan PSAK No. 45: (1) Laporan Posisi Keuangan Laporan posisi keuangan mencakup entitas nirlaba secara keseluruhan dan menyajikan total aset, liabilitas, dan aset neto. (2) Laporan Aktivitas Laporan aktivitas mencakup entitas nirlaba secara keseluruhan dan menyajikan perubahan jumlah aset neto selama suatu periode. (3) Laporan Arus Kas Laporan arus kas harus melaporkan arus kas selama periode tertentu dan diklasifikasi menurut aktivitas operasi,investasi, dan pendanaan. (4) Catatan Atas Laporan Keuangan Catatan atas laporan keuangan dapat berupa: (a) Perincian dari suatu perkiraan yang disajikan, misalnya aktiva tetap. (b) Kebijakan akuntansi yang dilakukan, misalnya metode penyusutan serta tarif yang digunakan untuk aktiva tetap lembaga, metode pencatatan piutang yang tidak dapat ditagih serta presentase yang digunakan untuk pencadangannya (IAI 2015).

IAI (2015) dalam PSAK No. 45 menyatakan bahwa "Tujuan utama Iaporan keuangan adalah menyediakan informasi yang relevan untuk memenuhi kepentingan para pemberi sumber daya yang tidak mengharapkan pembayaran kembali, anggota, kreditor, dan pihak lain yang menyediakan sumber daya bagi entitas nirlaba.

\section{PSAK 109}

Ikatan Akuntan Indonesia (IAI) telah mengeluarkan PSAK 109 untuk akuntansi zakat, infak/sedekah. PSAK 109 ini akan menyeragamkan pencatatan pada lembaga pengelola zakat yang selama ini sebagian besar menggunakan PSAK 45 untuk organisasi non laba. Sebelum ada PSAK 109, lembaga pengelola zakat telah membuat laporan keuangan tetapi tidak ada keseragaman antara satu lembaga pengelola zakat dengan lembaga pengelola zakat yang lain. Hal ini tentu menyulitkan bagi berbagai kalangan untuk memahami maksud dan tujuan dari laporan keuangan tersebut. Laporan keuangan seharusnya informatif dan dapat dibandingkan antara laporan keuangan lembaga pengelola zakat satu dengan lembaga pengelola zakat yang lain. Laporan keuangan amil menurut PSAK 109 adalah laporan posisi keuangan (neraca), laporan perubahan dana, laporan perubahan aset kelolaan, laporan arus kas dan catatan atas laporan keuangan. Neraca dan laporan penerimaan, pengeluaran dan perubahan dana untuk organisasi zakat, infak, dan sedekah ini merupakan gabungan dari dua dana tersebut, yaitu dana zakat dan dana sedekah, sedangkan laporan perubahan posisi keuangan dan catatan atas laporan keuangan perlu ditambahkan sehingga menjadi laporan keuangan yang menyeluruh yang menggambarkan kondisi keuangan organisasi pengelola zakat. Dalam catatan ini menjelaskan mengenai kebijakankebijakan akuntansi dan prosedur yang diterapkan oleh organisasi yang bersangkutan sehingga diperoleh angka-angka dalam laporan keuangan tersebut (IAI 2015). 


\section{Akuntansi Untuk Zakat}

(1) Penerimaan zakat diakui pada saat kas atau aset nonkas diterima dan diakui sebagai penambah dana zakat. Jika diterima dalam bentuk kas, diakui sebesar jumlah yang diterima tetapi jika dalam bentuk non kas sebesar nilai wajar aset. Penentuan nilai wajar aset nonkas yang diterima menggunakan harga pasar. Jika harga pasar tidak tersedia, maka dapat menggunakan metode penentuan nilai wajar lainnya sesuai dengan PSAK yang relevan. (2) Jika muzakki menentukan mustahik yang harus menerima penyaluran zakat melalui amil, maka aset zakat yang diterima seluruhnya diakui sebagai dana zakat dan tidak ada bagian amil atas zakat yang diterima dan amil dapat menerima ujrah atas kegiatan penyaluran zakat. Jika atas jasa tersebut amil mendapatkan ujrah/fee, maka diakui sebagai penambah dana amil. (3) Penurunan nilai aset zakat diakui sebagai: (a) Pengurang dana zakat, jika terjadi tidak disebabkan oleh kelalaian amil. Kerugian dan pengurang dana amil, jika disebabkan oleh kelalaian amil. (b) Zakat yang disalurkan kepada mustahik, diakui sebagai pengurang dana zakat dengan keterangan sesuai dengan kelompok mustahik termasuk jika disalurkan kepada Amil, sebesar: a) Jumlah yang diserahkan, jika pemberian dilakukan dalam bentuk kas, jurnal Jumlah tercatat, jika pemberian dilakukan dalam bentuk aset nonkas, jurnal Amil berhak mengambil bagian dari zakat untuk menutup biaya operasional dalam menjalankan fungsinya. b) Beban penghimpunan dan penyaluran zakat harus diambil dari porsi amil. c) Zakat dikatakan telah disalurkan kepada mustahik-non-amil hanya bila telah diterima oleh mustahiknon-amil tersebut. d) Apabila zakat disalurkan melalui amil lain, maka diakui sebagai piutang penyaluran dan bagi amil yang menerima diakui sebagai liabilitas (utang) penyaluran. Piutang dan liabilitas berkurang ketika zakat disalurkan. Amil lain tidak berhak mengambil bagian dari dana zakat, namun dapat memperoleh ujrah dari amil sebelumnya, PSAK No. 109 (IAI 2015).

Jenis-jenis Laporan Keuangan Entitas Nirlaba Unsur-unsur laporan keuangan berdasarkan PSAK No. 109: (1) Laporan Posisi Keuangan Laporan posisi keuangan mencakup entitas nirlaba secara keseluruhan dan menyajikan total aset, liabilitas, dan aset neto. (2) Laporan Aktivitas Laporan aktivitas mencakup entitas nirlaba secara keseluruhan dan menyajikan perubahan jumlah aset neto selama suatu periode. (3) Laporan Arus Kas Laporan arus kas harus melaporkan arus kas selama periode tertentu dan diklasifikasi menurut aktivitas operasi,investasi, dan pendanaan. (4) Catatan Atas Laporan Keuangan Catatan atas laporan keuangan (IAI 2015).

\section{PEMBAHASAN}

Perbedaan perlakuan akuntansi PSAK 45 dan PSAK 109 yang sangat mendasar kedua PSAK itu adalah pada PSAK 109 adalah adanya unsur syariah sedangkan pada PSAK 45 tidak ada unsur syariah, dikarenakan, PSAK 109 merupakan bagian dari standar akuntansi keuangan syariah yang menerapkan kebijakan sesuai dengan prinsip syariah dalam semua transaksi dan kegiatan usahanya. (IAI 2015, 4).

Pada dasar PSAK 45 adalah standar atau panduan yang mengatur tentang keuangan untuk organisasi nirlaba pertama kali dikeluarkan oleh Ikatan Akuntan Indonesia (IAI) pada tahun 1997. Panduan tersebut adalah Pernyataan Akuntansi 
Keuangan (PSAK) Nomor 45 Tentang Pelaporan Keuangan Organisasi Nirlaba. Dan semua organisasi nirlaba diwajibkan menggunakan PSAK 45 pada tahun 2000. Dibuatnya standar akuntansi untuk organisasi nirlaba tersebut dilatarbelakangi oleh tuntutan terhadap transparansi keuangan yang bertujuan untuk menyeragamkan penyajian laporan keuangan lembaga nirlaba sehingga laporan keuangan dapat lebih mudah dipahami, relevan, andal, dan memiliki daya banding yang tinggi. PSAK 45 mengatur tentang format laporan keuangan lembaga nirlaba, isi atau akun-akun apa saja yang ada di dalamnya, pengukuran atau nilai akun yang perlu ditampilkan dan sebagainya. (Nainggolan 2012, 1). Pada perkembangannya, PSAK 45 pernah mengalami beberapa kali perubahan, dan revisi terbaru yakni pada tahun 2011 PSAK 45 (revisi 2011) tentang Pelaporan Keuangan Entitas Nirlaba telah disahkan oleh Dewan Standar.

Akuntansi Keuangan pada tanggal 8 April 2011. Dan PSAK 45 (revisi 2011) ini menggantikan PSAK 45 tentang Pelaporan Keuangan Entitas Nirlaba yang telah dikeluarkan pada 23 Desember 2007. Kerangka Dasar Standar Akuntansi Nirlaba Kerangka dasar standar akuntansi nirlaba merujuk kepada Kerangka Dasar Penyusunan dan Penyajian Laporan Keuangan (KDPPLK). Tujuan laporan keuangan lembaga nirlaba sesuai KDPPLK (IAI 2011, 4-5) ada 3 (tiga) antara lain: (1) Untuk menyediakan informasi yang menyangkut posisi keuangan, kinerja, serta perubahan posisi keuangan suatu perusahaan yang bermanfaat bagi sejumlah sejumlah besar pemakai dalam pengambilan keputusan ekonomi; (2) Untuk memenuhi kebutuhan bersama sebagian besar pemakai. (3) Untuk menunjukkan apa yang telah dilakukan oleh manajemen, atau sebagai pertanggungjawaban manajemen atas sumber daya yang dipercayakan kepadanya. Asumsi dasar akuntansinya (IAI 2011, 6) adalah dasar akrual dan kelangsungan usaha. Dengan dasar akrual, pengaruh transaksi dan peristiwa lain diakui dan dicatat dalam catatan akuntansi serta dilaporkan dalam laporan keuangan pada periode yang bersangkutan. Laporan yang disusun atas dasar akrual memberikan informasi kepada pemakai tidak hanya transaksi masa lalu yang melibatkan penerimaan dan pembayaran kas saja, tetapi juga kewajiban kas yang harus dibayar di masa depan, serta mempresentasikan kas yang akan diterima di masa depan. Selanjutnya, laporan keuangan disusun atas dasar asumsi kelangsungan usaha perusahaan dan akan melanjutkan usahanya di masa depan. Organisasi nirlaba harus memiliki karakteristik kualitatif, yakni: dapat dipahami, relevan, keandalan, dan dapat diperbandingkan (IAI 2011, 10).

Standar akuntansi zakat di Indonesia (PSAK 109) mulai berlaku paling lambat 1 Januari 2012. PSAK 109 disahkan oleh Dewan Standar Akuntansi Syariah - Ikatan Akuntan Indonesia (DSAS - IAI) pada tanggal 6 April 2010. Untuk meminta fatwa, DSAS - IAI menulis surat kepada Dewan Syariah Nasional - Majelis Ulama Indonesia (DSN-MUI) pada 4 Mei 2010 yang kemudian dikeluarkan fatwa pada tanggal 16 Agustus 2011. Maka sejak tanggal tersebut PSAK 109 dapat diterapkan. Didalam PSAK tersebut dijelaskan bahwa penerapannya dimulai 1 Januari 2012. Kerangka dasar standar akuntansi zakat merujuk kepada Kerangka Dasar Penyusunan dan Penyajian Laporan Keuangan Syariah (KDPPLKS). Tujuan laporan keuangan lembaga zakat sesuai KDPPLKS (Siswantoro 2015, 3) antara lain: (1) Meningkatkan kepatuhan terhadap prinsip syariah; (2) Informasi aset, kewajiban, pendapatan, dan beban yang tidak sesuai dengan prinsip syariah bila ada, dan bagaimana perolehan serta penggunaannya; 
(3) Informasi untuk membantu mengevaluasi pemenuhan tanggung jawab entitas syariah terhadap amanah; (4) Untuk tujuan ke empat, sudah tercakup dalam lembaga zakat itu sendiri, yakni fungsi sosial. Asumsi dasar akuntansinya (IAI 2013, 8) sebagai berikut: (1) Dasar Akrual. Dalam hal ini, untuk menghitungan pendapatan pada saat pembagian hasil usaha atau keuntungan bruto, menggunakan dasar kas. (2) Kelangsungan Usaha. Sama halnya dengan entitas lain pada umumnya, entitas syariah pun tidak berkeinginan untuk melikuidasi kelangsungan usahanya. Apabila maksud tersebut timbul, maka laporan keuangan harus disusun dengan dasar yang berbeda dan dasar yang digunakan harus diungkapkan. Laporan keuangan amil zakat juga harus memenuhi kriteria yaitu harus mudah dipahami, relevan, andal, dan dapat dibandingkan.

\section{Rekonstruksi PSAK yang Relevan Untuk Masjid}

Perlakuan akutansi yang dapat diberlakuan pada organisasi nirlaba yaitu pada PSAK 45 yaitu secara keseluruhan meliputi total asset, total utang dan asset netto.

Laporan aktivitas menjelaskan dan meliputi entitas nirlaba secara keseluruhan dan menyajikan perubahan jumlah aset neto selama suatu periode. Perubahan asset neto mencerminkan perubahan pada asset organisasi nirlaba sebagai aktivitas dalam perusahaan nirlaba. Tujuan dari lapora aktivitas dalam organisasi nirlaba yaitu dapat digunakan untuk mengevaluasi kinerja dalam suatu periode; menilai upaya, kemampuan, dan kesinambungan entitas nirlaba dan memberikan jasa; dan menilai pelaksanaan tanggung jawab.

Laporan Arus Kas memiliki tujuan utama menyajikan informasi mengenai penerimaan dan pengeluaran kas dalam suatu periode. Laporan arus kas harus menyajikan arus kas selamasatu periode yang diklasifikasikan menurut aktivitas operasi,aktivitas investasi, dan aktivitas pendanaan. Arus kas dari aktivitas operasi mencakup kas dari pendapatan jasa, kas daripenyumbang, penerimaan lain-lain dikurangi dengan kas yang dibayarkan kepada karyawan dan pembayaran beban usaha.

Dan yang terakhir dalam PSAK 45 adalah Catatan Atas Laporan keuangan, yaitu bagian tidak terpisahkan dari laporan keuangan itu sendiri yang menjelaskan laporan keuangan dari kebijakan akuntansinya. Catatan Atas Laporan Keuangan terbagi menjadi tiga struktu yaitu: (1) Menyajikan informasi tentang dasar penyusunan laporan keuangan dan kebijakan akuntansi tertentu yang digunakan. (2) Mengungkapkan informasi yang disyaratkan oleh SAK yang tidak disajikan dibagian manapun dalam laporan keuangan. (3) Memberikan informasi yang tidak disajikan di bagian manapun dalam laporan keuangan, tetapiinformasi tersebut relevan untuk memahami laporan keuangan. 


\section{Gambar 1 Contoh Laporan Keuangan PSAK 45}

\begin{tabular}{|c|c|c|c|c|c|c|}
\hline \multirow{2}{*}{\multicolumn{4}{|c|}{$\begin{array}{c}\text { Neraca (I.aparan Ioxixi Keluangan) } \\
\text { BAZ -XXX" } \\
\text { Per } 31 \text { Dexember } 2 X X Z\end{array}$}} & \multicolumn{3}{|c|}{ 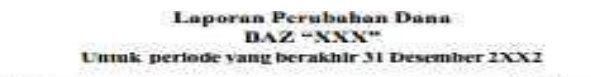 } \\
\hline & & & & \multicolumn{2}{|c|}{ Keterangan } & KED \\
\hline Keterangan & $\mathbf{R} p$ & Kcterangan & $\mathbf{R p}$ & \multirow{2}{*}{\multicolumn{2}{|c|}{ 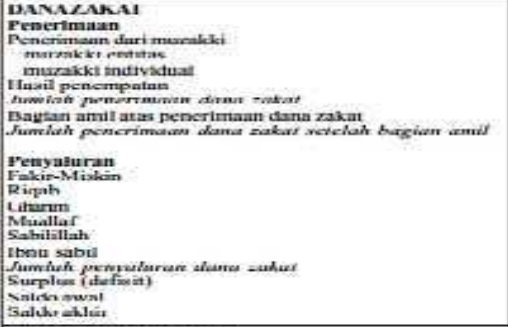 }} & \\
\hline $\begin{array}{l}\text { Aser } \\
\text { Aver luncur } \\
\text { Kus dan xcluri kus } \\
\text { Insmriman knusr can } \\
\text { Piuluas }\end{array}$ & $\begin{array}{l}\mathrm{xxz} \\
\mathrm{x} \times \mathrm{x} \\
\mathrm{xxz}\end{array}$ & 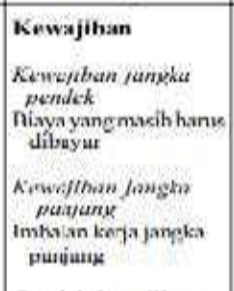 & $\mathrm{xxx}$ & & & 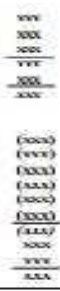 \\
\hline 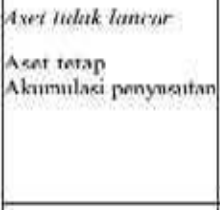 & $(\cdots$, & 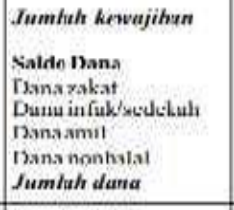 & $\begin{array}{l}x \times x \\
x \times x \\
x \neq x \\
x \ldots x \\
x x x\end{array}$ & \multirow{2}{*}{\multicolumn{2}{|c|}{ 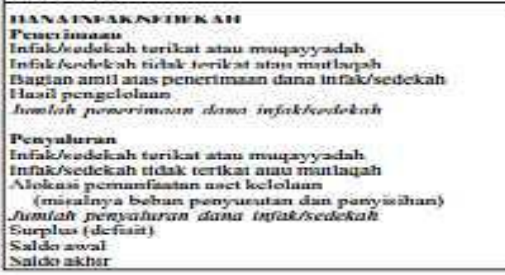 }} & 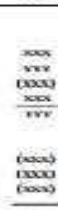 \\
\hline Jumbah ased & $\cdots$ & $\begin{array}{l}\text { Jumbah Ninofihan } \\
\text { dan Safle Dana }\end{array}$ & $\cdots$ & & & 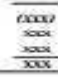 \\
\hline 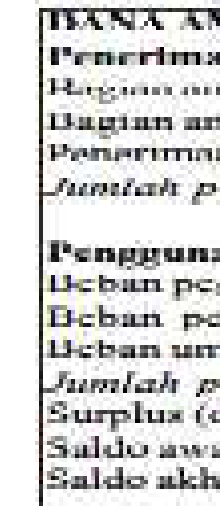 & 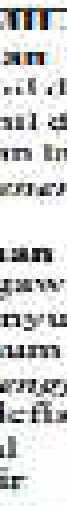 & 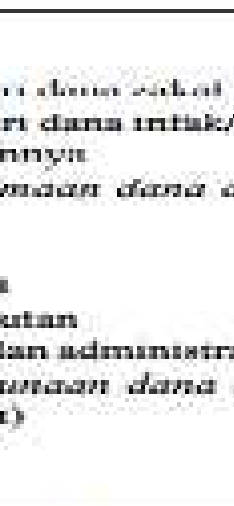 & ani & 19u & 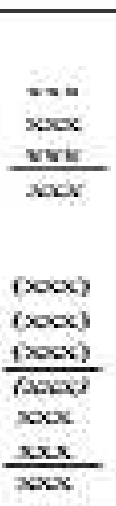 & \\
\hline 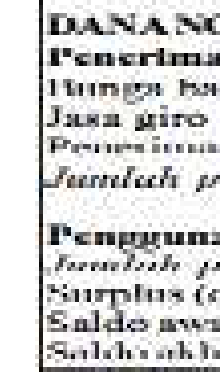 & $\begin{array}{l}\text { min } \\
\text { an } \\
\text { nk } \\
\text { int } \\
\text { int } \\
\text { int } \\
\text { in }\end{array}$ & 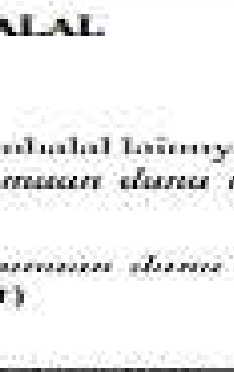 & thent & & $\frac{\operatorname{trary}}{\operatorname{men}}$ & \\
\hline \multicolumn{5}{|c|}{ 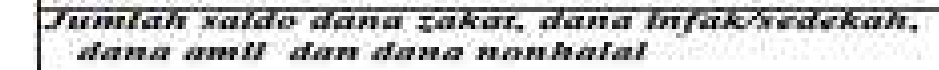 } & \multicolumn{2}{|l|}{ WE } \\
\hline
\end{tabular}

Perlakuan PSAK pada masjid juga bisa diterapkan pada PSAK 109 yaitu standar yang menitik beratkan pada pentingnya pelaporan pada pengelolaan dana zakat, infak,dan sedekah. Laporan posisi keuangan hampir sama dengan PSAK 45 yaitu meliputi total asset, total utang dan asset netto.

Laporan perubahan dana adalah laporan yang menjelaskan pemasukan dana zakat dan penyalurannya sebagai bahan evaluasi kinerja dari organisasi yang mengelola dana zakat dan pelaksanaan penyaluran dana zakat. 


\section{Gambar 2 Contoh Laporan Keuangan PSAK 109}

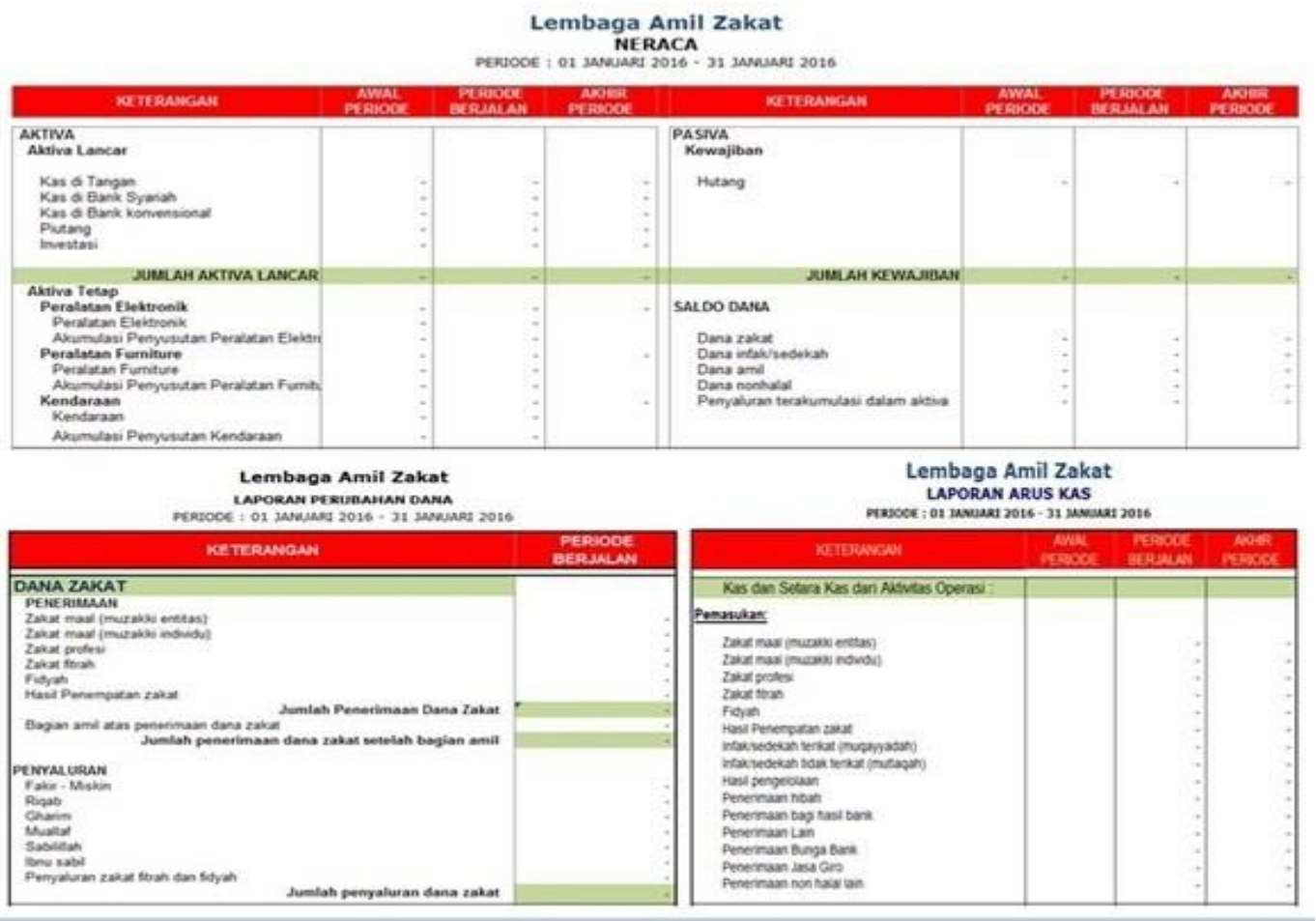

Seiring dengan perkembangannya masjid menjelma menjadi organisasi yang mengelola banyak dana tidak hanya zakat tetapi dana dari masyarakat untuk kemaslahatan bersama. Semakin banyak dana yang dikelola masjid semakin berat tantangan masjid dalam mengelola dana masyarakat yang masuk maupun dalam penggunaan dana tersebut. Akuntansi dengan PSAK 45 dan PSAK 109 menjembatani untuk takmir masjid dalam melakukan pelaporan keuangan agar tercapai akuntabilitas dan transparansi masjid. Tetapi sisi kepraktisan menjadi sangat penting karena banyak takmir masjid yang belum paham terhadap sisi pelaporan keuangan yang sesuai kaidah. Dari penelitian pustaka ini bisa ditarik bahwa semakin berkembangannya pengelolaan masjid maka pelaporan akan lebih komprehensif menggunakan PSAK 45 karena dalam PSAK 45 diatur semua pelaporan dana tidak hanya dari zakat. Akan tetapi dalam pelaporan penggunaan dana zakat bisa diadopsi menggunakan PSAK 109 sebagai pelaporan terpisah.

Untuk mewujudkan akuntabilitas publik yang baik dan pengembangan masjid yang lebih besar, akan diperlukan sumber pendanaan yang lebih besar juga sehingga organisasi dapat mempertimbangkan mencari sumber dana alternatif seperti bantuan lembaga donor internasional yang mensyaratkan audit laporan keuangan lembaga independen seperti Kantor Akuntan Publik (KAP) (Halim 2013, 466). Kondisi tersebut menjadi kebutuhan dan harus diimplementasikan.

\section{KESIMPULAN}

Berdasarakan pembahasan diatas seiring dengan perkembangan masjid yang mengelola dana dari masyarakat, maka PSAK 45 jauh lebih komprensif karena pelaporan lebih mencerminkan apa yang terjadi dilapangan karena masjid tidak hanya mengelola dana zakat saja tetapi juga mengelola dana dari bantuan 
maupun yang dikumpulkan dari masyarakat. Akan tetapi dalam pelaksanaan penggunaan PSAK memang harus memperhatikan sisi kompleksitas dan tidak menyulitkan takmir masjid, karena pengelola masjid masih banyak yang awam dari akuntansi. Dan masjd juga bisa menggunakan PSAK 109 dalam melaporkan penggunaan dana zakat sebagai bagian terpisah dari pelaporan dan diungkapkan dalam Catatan atas Laporan keuangan.

\section{DAFTAR PUSTAKA}

Ayub, Moh. E. 1996. Manajemen Masjid. Jakarta: Gema Insani Press.

Azwari, Peny Cahaya dan Ayke Nuraliati. 2018. "Rekonstruksi Perlakuan Akuntansi Untuk Entitastempat Ibadah (Studi Perlakuan Akuntansi Organisasi Masjid Berdasarkan PSAK 45 Dan PSAK 109)". I-Finance: A Research Journal on Islamic Finance 4 (1), 84-101. https://doi.org/https://doi.org/10.19109/ifinance.v4i1.2304.

Bastian, Indra. 2006. Akuntansi Sektor Publik: Suatu Pengantar. Jakarta: Erlangga.

Halim, Abdul. 2013. Akuntansi Sektor Publik. Jakarta: Salemba Empat.

Hanafi, Roby. 2015. "Akuntabilitas dan Pengelolaan Keuangan di Masjid Melalui Pendekatan Fenomenologi (Studi Empiris pada Masjid Nurusy Syifa' Surakarta)". Naskah Publikasi Universitas Muhammadiyah Surakarta.

Ikatan Akuntansi Indonesia. 2011. Pernyataan Standar Akuntansi Keuangan. Jakarta.

Ikatan Akuntansi Indonesia. 2013. Pernyataan Standar Akuntansi Keuangan. Jakarta.

Ikatan Akuntansi Indonesia. 2015. Pernyataan Standar Akuntansi Keuangan. Jakarta.

Rahayu, Ruci Arizanda; Unti Ludigdo and M. Achsin. 2017. "Transparency and Accountability of Financial Report at Surabaya Al Akbar National Mosque". Research Journal of Finance and Accounting 8 (18), 1-6.

Simanjuntak, D. A. dan Y. Januarsi 2011. "Akuntabilitas dan Pengelolaan Keuangan di Masjid". Simposium Nasional Akuntansi XIV Aceh.

Siskawati, Eka; Ferdawati dan Firman Surya. 2016. "Pemaknaan Akuntabilitas Masjid: Bagaimana Masjid Dan Masyarakat Saling Memakmurkan?”. Jurnal Akuntansi Multiparadigma 7 (1), 70-80. http://dx.doi.org/10.18202/jamal.2016.04.7006

Yahya, I. 2006. "Akuntabilitas dan Pengelolaan Keuangan Daerah". Jurnal Sistem Teknik Industri 7 (4). 